\title{
Chemical condition for the appearance of a negative Ce anomaly in stream waters and groundwaters
}

\author{
Mayumi Seto* and TASUKu AKagi \\ Laboratory of Metallogenic Geochemistry, Department of Earth and Planetary Sciences, Faculty of Sciences, Kyushu University, \\ Hakozaki 6-10-1, Higashi-ku, Fukuoka 812-8581, Japan
}

(Received October 17, 2007; Accepted April 15, 2008)

\begin{abstract}
Nine publications showing REE data in groundwaters and river water were examined to understand the general condition of terrestrial water where a negative Ce anomaly develops. It was found that the negative Ce anomaly only appeared when $\mathrm{Fe}, \mathrm{Mn}$ and dissolved organic carbon (DOC) concentrations were low (Fe and $\mathrm{Mn}<5 \times 10^{-5}$ mol/L and DOC $<10$ $\mathrm{mg} / \mathrm{L})$. Assuming that $\mathrm{Ce}^{3+}$ and $\mathrm{Fe}^{2+}$ concentrations were limited by the formation of cerianite and ferrihydrite, respective redox potential (Eh) was calculated from each of $\mathrm{Ce}^{3+}$ and $\mathrm{Fe}^{2+}$ concentrations. For data sets displaying Ce anomalies, the calculated Ehs $(c E h \mathrm{~s})$ showed a 1:1 relationship between $\mathrm{Ce}$ and Fe. This relationship indicates that the absolute concentration of $\mathrm{Ce}$ in natural water may be thermodynamically determined in situ by Eh and $\mathrm{pH}$ when concentrations of $\mathrm{Fe}$, Mn and DOC are poor.
\end{abstract}

Keywords: Ce anomaly, iron, manganese, Rare Earth Element, Redox processes, dissolved organic carbon

\section{INTRODUCTION}

The distribution of rare earth elements (REEs) in waters has been mostly used as an index of water/rock interaction processes or as a hydrological tracer due to the improvement of suitable analytical techniques during recent decades (Hall et al., 1995). Ample evidence has been already provided to show that REEs could be significantly mobilized during weathering, alteration and diagenesis processes (Hellman and Henderson, 1977; Nesbitt, 1979; Ward, 1986; Wood, 1990) and chemical weathering reactions leads to extensive fractionation in REE composition among river waters, continental rocks and river suspended particles (Goldstein and Jacobsen, 1988; Elderfield et al., 1990; Sholkovitz, 1993, 1995).

Cerium often behaves differently from the neighboring REEs due to its low ionization potential of $\mathrm{Ce}^{3+}$. The value of the $\mathrm{Ce}$ fraction relative to neighboring trivalent REEs (La and Pr) is termed the "Ce anomaly" and is defined as

$$
\text { Ce anomaly }=\frac{(\mathrm{Ce})_{\mathrm{n}}}{\mathrm{Ce}^{*}}=\frac{(\mathrm{Ce})_{\mathrm{n}}}{\sqrt{(\mathrm{La})_{\mathrm{n}}(\mathrm{Pr})_{\mathrm{n}}}}
$$

where $(\mathrm{Ln})_{\mathrm{n}}$ is a normalized concentration of a lanthanide element, $\mathrm{Ln}$.

*Corresponding author (e-mail: mseto@kyudai.jp)

Copyright $@ 2008$ by The Geochemical Society of Japan.
Anomalies of Ce have been of particular interest following the anomaly's potential use as an indicator of water/rock interaction processes or as a hydrological tracer. Previous investigations have shown that fresh water, especially groundwater, exhibits REE patterns that closely resemble those of the rocks through which they have flowed (Smedley, 1991). Patino et al. (2003) indicated that a negative Ce anomaly could develop in corestones during spheroidal weathering of basalts due to immobilization of $\mathrm{Ce}^{4+}$ compared to other trivalent REEs, implying that the negative Ce anomaly may be a source related feature. However, other processes are important in constraining the appearances of $\mathrm{Ce}$ anomaly in fresh water. The removal of Ce may occur either as a result of $\mathrm{CeO}_{2}$ precipitation (Braun et al., 1998), or oxidative scavenging of $\mathrm{Ce}(\mathrm{IV})$ on the surface of $\mathrm{Fe}$ and $\mathrm{Mn}$ oxyhydroxides (De Carlo et al., 1998; Bau, 1999; Ohta and Kawabe, 2001). Furthermore, Moffett (1990) showed that the $\mathrm{Ce}$ (III) oxidation in seawater might be mediated by surface catalysis and microbial activity. Therefore, the $\mathrm{Ce}$ anomaly may be related to weathering, inorganic aquatic processes, or biological mediation.

In this study, we compiled some REE datasets in fresh water from the nine publications listed in Table 1. Using these datasets, we reviewed the necessary conditions of terrestrial water, which shows negative $\mathrm{Ce}$ anomalies. We then examined how the Ce anomaly develops under such conditions. In conclusion, we suggest that the Ce anomaly appears due to $\mathrm{Ce}^{3+} / \mathrm{CeO}_{2}$ equilibrium in the absence of organic matter. 
Table 1. Publications referred to in this study

\begin{tabular}{|c|c|c|c|}
\hline Reference & Water sample & Filter & Referred item \\
\hline Smedley (1991) & Groundwater & $0.45 \mu \mathrm{m}$ & $\mathrm{Ce}, \mathrm{Fe}, \mathrm{pH}, \mathrm{HCO}_{3}, \mathrm{SO}_{4}$ \\
\hline Dupré et al. (1996) & River water & $0.2 \mu \mathrm{m}$ & $\mathrm{Ce}, \mathrm{Fe}, \mathrm{pH}, \mathrm{HCO}_{3}, \mathrm{SO}_{4}$ \\
\hline Gaillardet et al. (1997) & River water & $0.2 \mu \mathrm{m}$ & $\mathrm{Ce}, \mathrm{Fe}, \mathrm{pH}, \mathrm{HCO}_{3}, \mathrm{SO}_{4}$ \\
\hline Braun et al. (1998) & Groundwater & $0.45 \mu \mathrm{m}$ & $\mathrm{Ce}, \mathrm{Fe}, \mathrm{pH}, \mathrm{HCO}_{3}, \mathrm{SO}_{4}$ \\
\hline Dia et al. (2000) & Groundwater & $0.22 \mu \mathrm{m}$ & $\mathrm{Ce}, \mathrm{Fe}, \mathrm{Mn}, \mathrm{pH}, \mathrm{Eh}, \mathrm{HCO}_{3}, \mathrm{SO}_{4}, \mathrm{DOC}$ \\
\hline Nakajima and Terakado (2003) & River and Groundwater & $0.45 \mu \mathrm{m}$ & $\mathrm{Ce}, \mathrm{Fe}, \mathrm{Mn}, \mathrm{pH}, \mathrm{HCO}_{3}, \mathrm{SO}_{4}$ \\
\hline Otsuka and Terakado (2003) & Groundwater & $0.45 \mu \mathrm{m}$ & $\mathrm{Ce}, \mathrm{Fe}, \mathrm{Mn}, \mathrm{pH}, \mathrm{HCO}_{3}, \mathrm{SO}_{4}$ \\
\hline Johannesson et al. (2004) & Surface water & $0.45 \mu \mathrm{m}$ & $\mathrm{Ce}, \mathrm{pH}, \mathrm{HCO}_{3}, \mathrm{SO}_{4}, \mathrm{DOC}$ \\
\hline Gruau et al. (2004) & Groundwater & $0.22 \mu \mathrm{m}$ & $\mathrm{Ce}, \mathrm{Fe}, \mathrm{Mn}, \mathrm{pH}, \mathrm{Eh}, \mathrm{HCO}_{3}, \mathrm{SO}_{4}, \mathrm{DOC}$ \\
\hline
\end{tabular}

\section{DATA SOURCE DESCRIPTION}

The data discussed in this paper are cited from nine publications (Table 1): Three references to riverwater (Dupré et al., 1996; Gaillardet et al., 1997; Nakajima and Terakado, 2003), five references to groundwater (Smedley, 1991; Braun et al., 1998; Dia et al., 2000; Otsuka and Terakado, 2003; Gruau et al., 2004) and one reference to swamp water (Johannesson et al., 2004). The nine publications cover most typical terrestrial waters ranging from a low (Dupré et al., 1996; Gaillardet et al., 1997) to high latitude (Dia et al., 2000; Gruau et al., 2004). For the data source descriptions, the reports and references therein are referred to.

Smedley (1991) investigated shallow groundwater samples from the Carnmenellis area, Cornwall, southwest England. Carnmenellis, at $252 \mathrm{~m}$, is the highest point in an area, which has a windswept landscape with patches of moorland and is generally devoid of tree. The average annual temperature for most of Cornwall is about $10^{\circ} \mathrm{C}$ with slightly lower temperatures at higher altitude (http:/ /www.metoffice.gov.uk/climate/uk/). The area includes the Carnmenellis granite and the immediately surrounding metasedimentary rocks (and some metabasite). 0.45 $\mu \mathrm{m}$ filtered samples were collected from shallow wells, boreholes, streams, and adits under low-flow conditions, during the autumn of 1988 .

The area Dupré et al. (1996) surveyed is the Congo Basin in Central Africa, which is dominated by rain forests of high productivity and arborescent savannahs and the basin is submitted to a wet tropical climate that constantly experiences precipitation higher than $1500 \mathrm{~mm} /$ yr and temperatures above $25^{\circ} \mathrm{C}$. Geologically, the central plain consists of Mesozoic sedimentary rocks and is bordered by Upper Proterozoic basement, composed of crystalline and metamorphic rocks associated with a shalelimestone system with a stratigraphic age of $900 \mathrm{Ma}$. The samples were collected from the Congo River and its tributaries between Bangui (Central African Republic) and Brazzaville (People's Republic of Congo) during the high water stage. Dissolved and suspended phases were isolated immediately after collection by filtration through $0.2 \mu \mathrm{m}$ filters.

The Amazon River and its main tributaries in Brazil were studied by Gaillardet et al. (1997) and were sampled during the high water stage of May 1989. This basin is covered by tropical rainforests and savannas. These highly productive ecosystems benefit from high rainfall $(2000-2300 \mathrm{~mm} / \mathrm{yr})$ and high mean temperature $\left(25^{\circ} \mathrm{C}\right)$. The Amazon Basin can be divided in four major morphostructural units and be composed of different lithologic characters (see Gaillardet et al. (1997) and literature referred to there). Samples were filtered on site through $0.2 \mu \mathrm{m}$ filters.

Braun et al. (1998) investigated groundwater in a lateritic soil cover in relation to a closed hydrographical system at Goyoum (East Cameroon). The region corresponds to the transition vegetation zone between rainforest and savannah. The altitude is between 600 and $700 \mathrm{~m}$. At Goyoum, the subequatorial climate is characterized by the alternation between two wet and two dry seasons of variable intensity. The mean annual air temperature is about $24^{\circ} \mathrm{C}$. In normal hydrological years, the mean annual rainfall is $1660 \mathrm{~mm}$. The soils are developed on a gneissic basement belonging to the Upper Proterozoic Basal Complex (Bessoles and Lasserre, 1977). The 0.45 $\mu \mathrm{m}$ filtered samples were collected at different points of the hydrographical system and in groudwaers.

Dia et al. (2000) studied fourteen well water samples and one spring located along two transects set up in a catchment from Western Europe (Kervidy/Coët-Dan catchment, France). The elevation range of the Kervidy/ Coët-Dan catchment is between 93 and $135 \mathrm{~m}$ and gentle slopes predominate. The land use in the catchment is intensive farming, which has caused heavy nitrate pollution of the waters of this catchment. The scale of the catch- 
ment is recognized by two hydrologically contrasted domains: (i) the hill-slope domain which comprises welldrained soils and where infiltration is dominant; and (ii) the bottomland which comprises waterlogged soils. The climate is humid temperate with a mean annual rainfall of $909 \mathrm{~mm}$. The bedrock is made of fissured and fractured upper Proterozoic schists. The samples used for determination of dissolved trace element and dissolved organic matter (DOC) concentrations were filtered on site using $0.22 \mu \mathrm{m}$ filters.

Nakajima and Terakado (2003) analyzed ten stream waters and one groundwater from the Rokko granite area, Japan. The elevation range of the study site is between 200 and $600 \mathrm{~m}$. Annual precipitation at Rokko Mountains is between 1200 to $1400 \mathrm{~mm}$, and the mean annual temperature in the region varies between 10 and $15^{\circ} \mathrm{C}$. The rocks and sediments in these sites were composed of the Rokko granite, which was a fine to coarse grained biotite granite of Mesozoic era. The water samples were immediately filtered through a $0.45 \mu \mathrm{m}$ membrane filters.

The samples Otsuka and Terakado (2003) investigated were groundwaters from the southern Nishinomiya district near the sites of Nakajima and Terakado (2003). The alluvial plain on which the urban areas of Nishinomiya and neighboring cities lie is located in the southeast of the Rokko Mountains. This groundwater is characterized by its high $\mathrm{PO}_{4}$ and low $\mathrm{Fe}$ concentrations. All the water samples were filtered through a $0.45 \mu \mathrm{m}$ filters.

The water samples Johannesson et al. (2004) studied were from the Great Dismal Swamp in southeastern Virginia and northeastern North Carolina, USA. The study focused on Lake Drummond (and its watershed), which is a shallow ( $2 \mathrm{~m}$ deep), blackwater lake located in the northern, Virginian section of the swamp. The samples are from its principal surface outflow waters. Annual precipitation at Lake Drummond is $1280 \mathrm{~mm}$, and the mean annual temperature in the region varies between 15 and $15.4^{\circ} \mathrm{C}$. Each water sample was immediately filtered on site using $0.45 \mu \mathrm{m}$ filters.

A small cathment in Western France (Petit Hermitage catchment) was studied by Gruau et al. (2004). The Le Home toposequence belongs to the Petit Hermitage Catchment, a fourth-order stream drainage basin located roughly $350 \mathrm{~km}$ west Paris, France. The land use is intensive farming dominated by crops and grass fields. The recognition of two distinct groups of waters based on their spatial location: (i) DOC-poor groundwater flowing below the hillslope domains; (ii) DOC-rich groundwater from the wetland domains, close to the river network. Annual precipitation at the region is $850 \mathrm{~mm}$, and the mean annual temperature is $11^{\circ} \mathrm{C}$. The bedrock comprises altered Upper Proterozoic schist. The waters were filtered on site using $0.22 \mu \mathrm{m}$ filters.

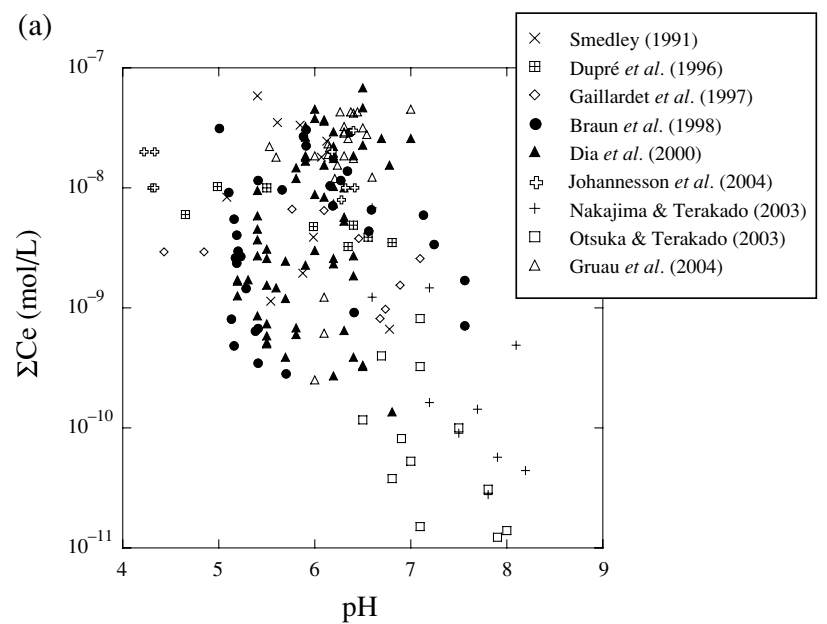

(b)

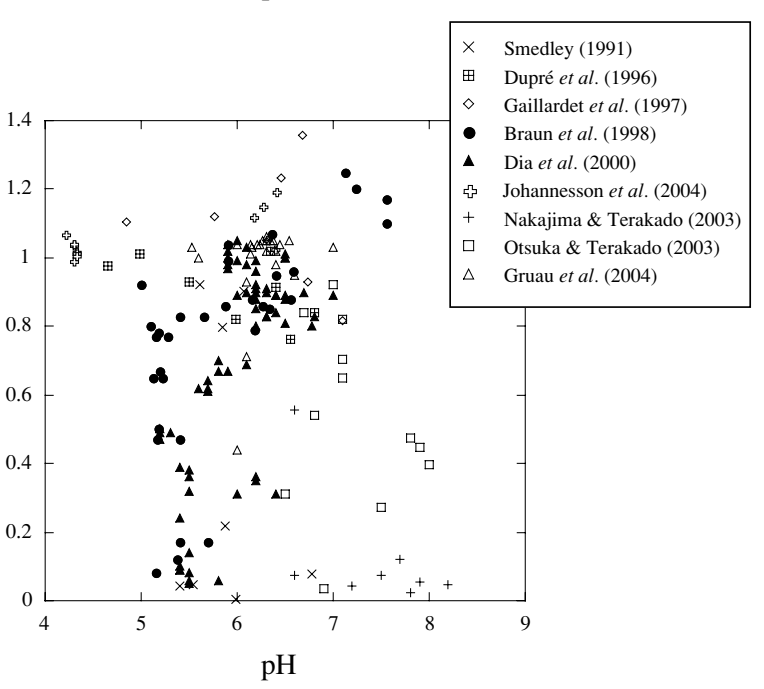

Fig. 1. Relationships between $\mathrm{pH}$ and (a) the concentration of $\Sigma C$ and (b) Ce anomaly (calculated from Eq. (1)) for the data sets from the 9 publications listed in Table 1.

\section{DISCUSSION}

\section{Effect of $p H$}

Figures 1(a) and (b) show the observed values of $\Sigma \mathrm{Ce}$ and the $\mathrm{Ce}$ anomaly against $\mathrm{pH}$ conditions, respectively. Ce data cited here are assumed to be the sum of (i) free $\mathrm{Ce}^{3+}$, (ii) $\mathrm{Ce}(\mathrm{III})$ or $\mathrm{Ce}(\mathrm{IV})$ complexes with inorganic ions (e.g., $\mathrm{HCO}_{3}^{-}$and $\mathrm{OH}^{-}$) or dissolved organic matter, and (iii) small Ce particulates adsorbed on to organic colloids. It has been demonstrated that samples filtered with 0.45 and $0.22 \mu \mathrm{m}$ filters included not only truly dissolved REE but also small particulate or colloidal phases (Lawrence and Kamber, 2006; Lawrence et al., 2006; Pourret et al., $2007 \mathrm{a}, \mathrm{b})$. We use here the term " $\Sigma \mathrm{Ce}$ " as Ce that passes through the filters employed for each sampling, i.e., its truly dissolved, small particulate, and colloidal phases and the term " $\mathrm{Ce}^{3+}$ " as Ce concentration excluding the con- 
(a)

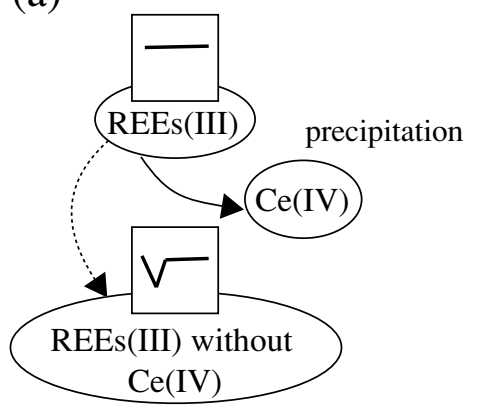

(b)

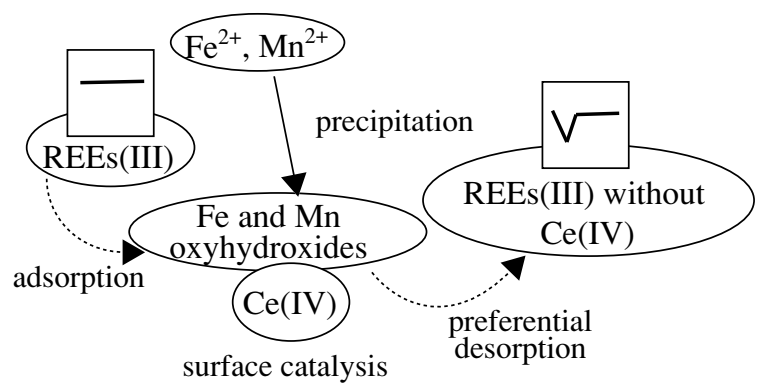

Fig. 2. Conceptual diagrams illustrating (a) independent precipitation of $\mathrm{Ce}$ and $(b)$ oxidative scavenging of $C e$.

(a)

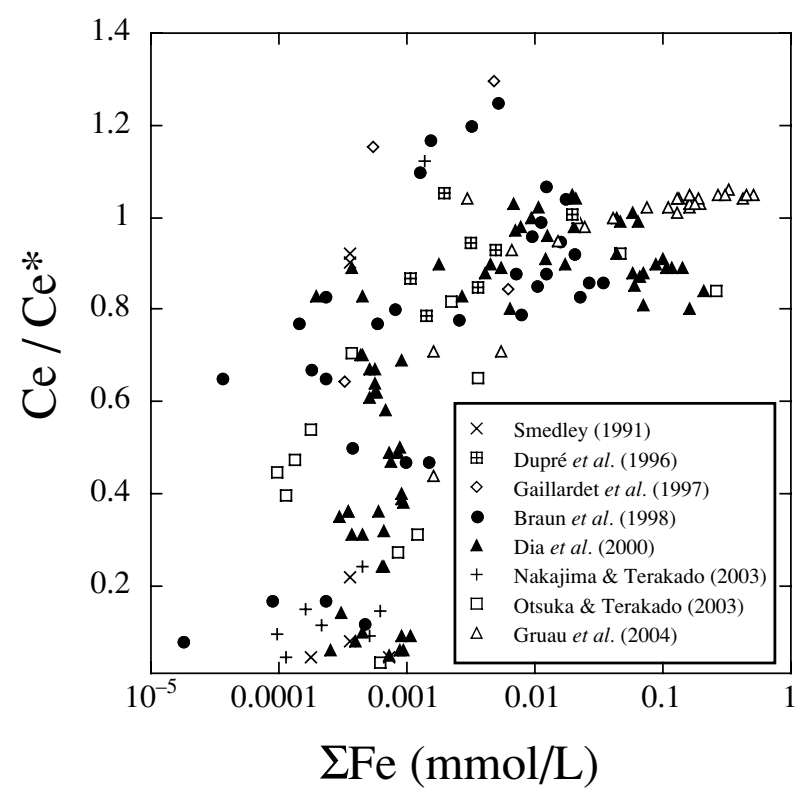

tributions of inorganic ligands (see Appendix), although it does not actually mean the free $\mathrm{Ce}^{3+}$.

The concentration of $\sum \mathrm{Ce}$ roughly increases as $\mathrm{pH}$ decreases (Fig. 1(a)), implying that the absolute abundance of $\mathrm{Ce}$ is globally controlled by $\mathrm{pH}$ condition. This is consistent with previous studies, which revealed that the REEs, especially LREEs, dissolved concentrations decreased with increasing $\mathrm{pH}$ (Goldstein and Jacobsen, 1988; Byrne and Sholkovitz, 1996; Dupré et al., 1996; Gaillardet et al., 1997; Johannesson and Burdige, 2007).

By contrast, there is no overall relationship between Ce anomaly and $\mathrm{pH}$. Deep negative Ce anomalies $(<0.6)$ have been measured in 5 aquifers (Smedley, 1991; Braun et al., 1998; Dia et al., 2000; Nakajima and Terakado, 2003; Otsuka and Terakado, 2003). Smedley (1991) suggested that those observed in the groundwaters that flood the metasediments from the Carmenellis region mirror the trends observed in their host-rocks and appear to be inherited from them by water-rock interaction involving chiefly REE enriched minerals. Alternatively, the anomaly has been interpreted as due to the selective removal of Ce from the waters by means of secondary cerianite $\left(\mathrm{CeO}_{2}\right)$ precipitation (Braun et al., 1998; Dia et al., 2000; Nakajima and Terakado, 2003; Otsuka and Terakado, 2003). We examine the condition in which negative $\mathrm{Ce}$ anomaly can develop by $\mathrm{Ce}($ III) oxidation and fractionation using existing data sets.

(b)

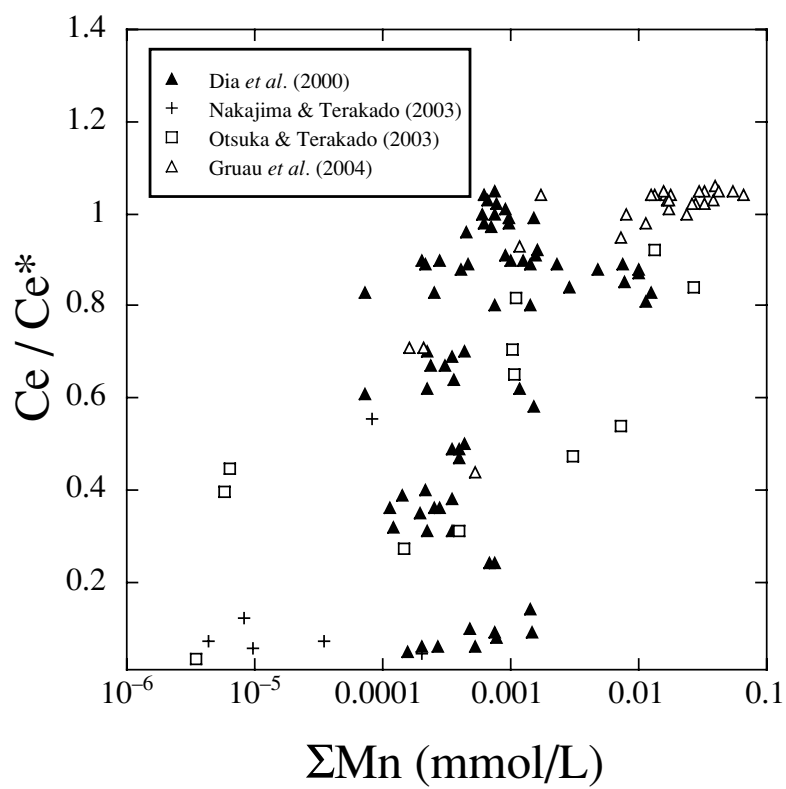

Fig. 3. Relationships between Ce anomaly and the concentrations of (a) $\Sigma F e$ and (c) $\Sigma M n$ for the data sets from the 9 publications listed in Table 1. 
Relationship between Ce anomaly and Fe, Mn and DOC

Two possible reactions have been considered to lead to Ce oxidation and fractionation (Fig. 2). The first is described in Braun et al. (1990) (see Fig. 2(a)):

$$
\mathrm{Ce}^{3+}+2 \mathrm{H}_{2} \mathrm{O} \rightarrow \mathrm{CeO}_{2} \text { (cerianite) }+4 \mathrm{H}^{+} .
$$

The reaction strongly depends on in situ Eh-pH condition and easily proceeds in the usual stream waters (Akagi and Masuda, 1998).

The second is the "oxidative scavenging" that is composed of three-stage process (Bau, 1999) (see Fig. 2(b)): (i) an initial sorption of $\mathrm{Ce}$ (III) together with the other REEs(III) onto Mn and Fe oxyhydroxides, followed by (ii) Ce oxidation due to surface catalysis on $\mathrm{Mn}$ (hydr)oxides (Koppenkastrop and De Carlo, 1992; Koppi et al., 1996) and $\mathrm{Fe}$ oxyhydroxides (Bau, 1999; Ohta and Kawabe, 2001), e.g.,

$$
\mathrm{Ce}^{3+}+\mathrm{MnOOH} \rightarrow \mathrm{CeO}_{2} \text { (cerianite) }+\mathrm{Mn}^{2+}+4 \mathrm{H}^{+}
$$

and (iii) the preferential desorption of REEs (III) including $\mathrm{Ce}$ (III) over $\mathrm{Ce}(\mathrm{IV})$.

We first examined contributions of Fe and $\mathrm{Mn}$ to the appearance of $\mathrm{Ce}$ anomaly. The concentrations of Fe were reported in 8 publications (Smedley, 1991; Dupré et al., 1996; Gaillardet et al., 1997; Braun et al., 1998; Dia et al., 2000; Nakajima and Terakado, 2003; Otsuka and Terakado, 2003; Gruau et al., 2004), Mn in 4 publications (Dia et al., 2000; Nakajima and Terakado, 2003; Otsuka and Terakado, 2003; Gruau et al., 2004).

Figures 3(a) and (b) display the relationships between the extent of $\mathrm{Ce}$ anomaly and the concentrations of $\Sigma \mathrm{Fe}$ and $\Sigma \mathrm{Mn}$. The terms " $\Sigma \mathrm{Fe}$ " and " $\Sigma \mathrm{Mn}$ " are here defined as the same as $\Sigma \mathrm{Ce}$, consisting of both colloidal and dissolved fractions of respective elements. It is clear that the negative $\mathrm{Ce}$ anomaly develops when $\Sigma \mathrm{Fe}$ and $\Sigma \mathrm{Mn}$ concentrations are low ( $\sum \mathrm{Fe}$ and $\left.\sum \mathrm{Mn}<5 \times 10^{-5} \mathrm{~mol} / \mathrm{L}\right)$, implying that $\mathrm{Ce}$ anomaly may not reflect the REE patterns of parental rocks but rather reflect the extent of $\mathrm{Ce}$ (III) oxidation. This could result both (i) from "independent" precipitations of $\mathrm{Ce}$ (IV) from $\mathrm{Fe}(\mathrm{III})$ or $\mathrm{Mn}$ (IV) precipitation, reflecting in situ $\mathrm{pH}-\mathrm{Eh}$ condition and (ii) from the oxidative scavenging of $\mathrm{Ce}$ with $\mathrm{Fe}$ and $\mathrm{Mn}$ oxyhydroxides. It will be again discussed in the following section.

Dia et al. (2000) and Gruau et al. (2004) explained the lack of $\mathrm{Ce}$ anomaly at high concentrations of $\mathrm{Fe}$ (II) and $\mathrm{Mn}$ (II) has something to do with the presence of organic compounds. They mentioned that Eh decreases coincided with increases of dissolved organic carbon (DOC), and $\mathrm{Mn}$ and Fe concentrations. They proposed two hypotheses to explain the absence of a negative $\mathrm{Ce}$ anomaly at a high DOC concentration. The first hypothesis is that (a)

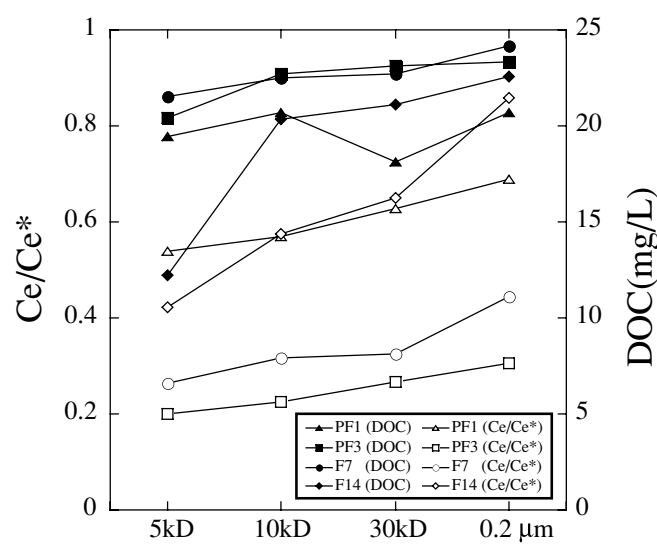

(b)

Filtration

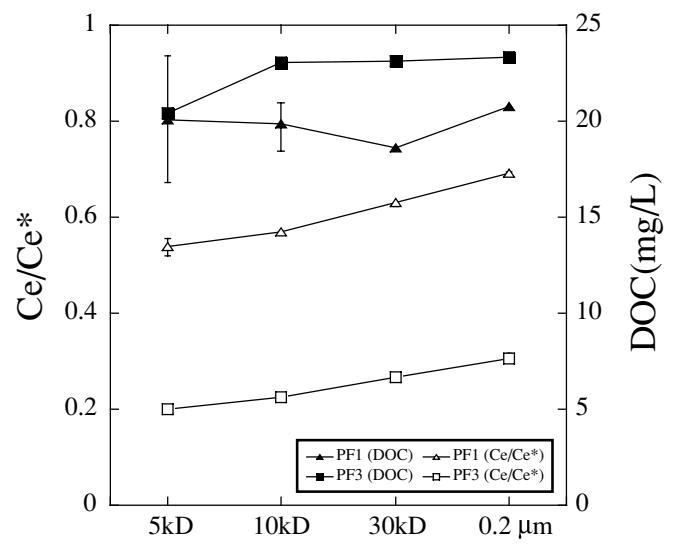

(c)

Filtration

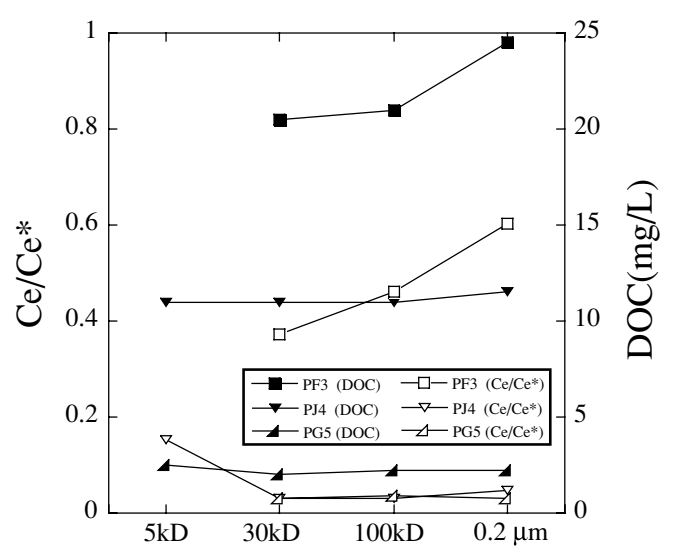

Filtration

Fig. 4. Ce anomaly and DOC concentrations of filtrates using the data reported by Dia et al. (2000) (a), Pourret et al. (2007a) (b) and Pourret et al. (2007b) (c). 


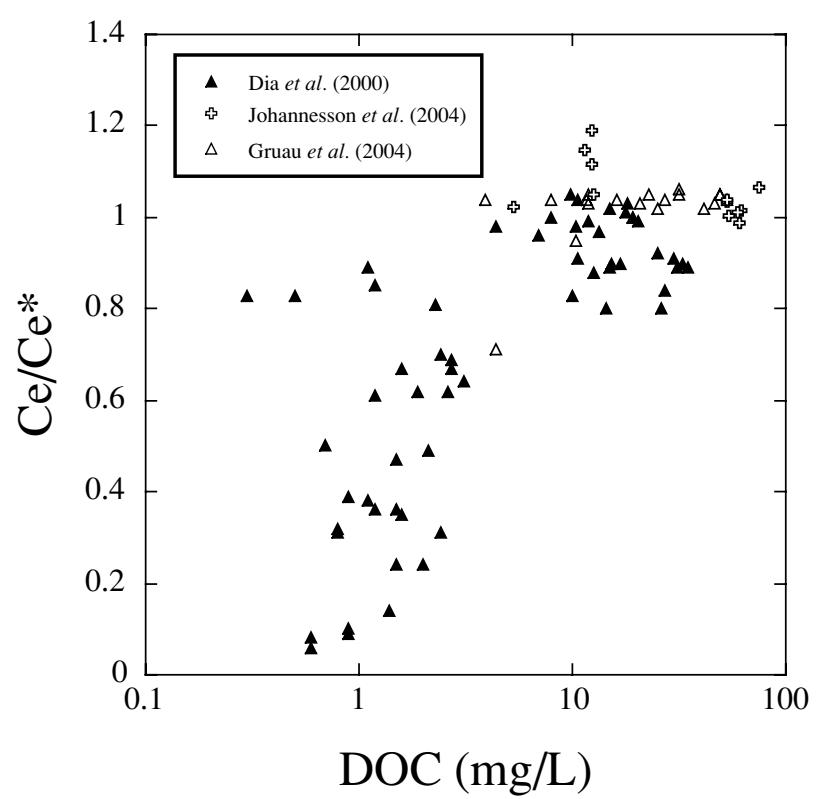

Fig. 5. Relationships between Ce anomaly and the DOC concentration for the data sets from the 3 publications listed in Table 1.

cerianite precipitation becomes impossible because of stabilization of $\mathrm{Ce}^{4+}$ (as other $\mathrm{REE}^{3+}$ ) by complexation with organic matter. It has been considered that REE complexation with organic matter could diminish negative Ce anomalies (Davranche et al., 2004, 2005). Recent experimental and modeling works have revealed that REE-HS (humic substance) complexes predominantly occur in natural water especially at pH from 6 to 10 (Tang and Johannesson, 2003; Sonke and Salters, 2006; Pourret et al., 2007a, c; Stern et al., 2007).

The second hypothesis is that cerianite is adsorbed onto colloids being then measured as a part of the solutions. Ultrafiltration experiments for the samples taken from the sites reported that a part of the REEs was controlled by the colloidal fraction (Dia et al., 2000; Pourret et al., 2007a, b). Figures 4(a), (b) and (c) show Ce/Ce* and DOC concentrations of filtrates using the data reported by Dia et al. (2000) and Pourret et al. (2007a, b). For the organic-rich sites (PF1, PF3, F7, F14), the Ce/ $\mathrm{Ce}^{*}$ of the filtrates decreased as the pore size of filters was smaller, implying that $\mathrm{Ce}$ (IV) complexed and/or adsorbed onto the organic and partly inorganic colloids (Figs. 4(a) and (b)). By contrast, the Ce anomaly and DOC concentration were independent of pore size for the organic-poor sites (PJ4, PG5) (Fig. 4(c)). This suggests that the colloidal and dissolved organic matter cannot diminish the Ce anomaly when DOC concentration is low $(<10 \mathrm{mg} / \mathrm{L})$. In a such case REEs might be predominantly affected by other factors and be approximated as a dis-
Table 2. Equilibrium constants used for calculations

\begin{tabular}{lll}
\hline Reaction & Constant & Ref. \\
\hline $\mathrm{Ce}^{3+}+2 \mathrm{H}_{2} \mathrm{O}=\mathrm{CeO}_{2}+4 \mathrm{H}^{+}+\mathrm{e}^{-}$ & $10^{-21.32}$ & $(1)$ \\
$\mathrm{Ce}^{3+}+\mathrm{SO}_{4}{ }^{2-}=\mathrm{CeSO}_{4}{ }^{+}$ & $10^{3.59}$ & $(2)$ \\
$\mathrm{Ce}^{3+}+\mathrm{HCO}_{3}{ }^{-}=\mathrm{CeCO}_{3}{ }^{2+}$ & $10^{2.31}$ & $(3)$ \\
$\mathrm{Ce}^{3+}+\mathrm{CO}_{3}{ }^{2-}=\mathrm{CeCO}_{3}{ }^{+}$ & $10^{7.06}$ & $(3)$ \\
$\mathrm{Ce}^{3+}+2 \mathrm{CO}_{3}{ }^{2-}=\mathrm{Ce}\left(\mathrm{CO}_{3}\right)_{2}{ }^{-}$ & $10^{11.76}$ & $(3)$ \\
$\mathrm{Ce}^{3+}+\mathrm{H}_{2} \mathrm{O}=\mathrm{CeOH}{ }^{2+}+\mathrm{H}^{+}$ & $10^{-8.34}$ & $(4)$ \\
$\mathrm{Ce}^{3+}+2 \mathrm{H}_{2} \mathrm{O}=\mathrm{Ce}(\mathrm{OH})_{2}{ }^{+}+2 \mathrm{H}^{+}$ & $10^{-15.0}$ \\
$\mathrm{Fe}^{2+}+3 \mathrm{H}_{2} \mathrm{O}=\mathrm{Fe}(\mathrm{OH})_{3}(\mathrm{am})+3 \mathrm{H}^{+}+\mathrm{e}^{-}$ & $10^{-25.59}$ \\
$\mathrm{Fe}^{2+}+\mathrm{SO}_{4}{ }^{2-}=\mathrm{FeSO}$ & \\
$\mathrm{Fe}^{2+}+\mathrm{HCO}_{3}{ }^{-}=\mathrm{FeCO}_{3}{ }^{+}$ & $10^{2.25}$ & $(5)$ \\
\hline
\end{tabular}

(1) Calculated from free energy data of Schumm et al. (1973), compiled by Brookins (1983); (2) Compiled by De Baar et al. (1988); (3) Schijf and Byrne (2004); (4) Klungness and Byrne (2000); (5) Langmuir (1997); (6) Nordstorm et al. (1990), compiled by Matsunaga et al. (1993).

solved fraction.

Figure 5 displays the relationships between the extent of Ce anomaly and the concentration of DOC reported by Dia et al. (2000), Gruau et al. (2004) and Johannesson et al. (2004). No Ce anomaly is seen for all the sites at which DOC $>10 \mathrm{mg} / \mathrm{L}$, whereas it sometimes develops at the sites of DOC $<10 \mathrm{mg} / \mathrm{L}$. It implies that Ce cannot be considered as a good tracer of redox conditions in organicrich waters as previously suggested by Dia et al. (2000), but may be used as it in organic-poor conditions.

Relationship between a Ce anomaly and redox condition

$\mathrm{Ce}$ anomaly may indicate in situ redox conditions both (i) by $\mathrm{Ce}^{3+} / \mathrm{CeO}_{2}$ reaction and (ii) by oxidative scavenging of $\mathrm{Ce}$ by $\mathrm{Fe}$ and $\mathrm{Mn}$ oxyhydroxides. As demonstrated by Akagi and Masuda (1998), assuming simply that cerianite $\left(\mathrm{CeO}_{2}\right)$ is a unique species of $\mathrm{Ce}(\mathrm{IV})$ in the water system and that the activity of solid phase is unity, the maximum activity of $\mathrm{Ce}^{3+}$ can be written as function of $\mathrm{Eh}$ and $\mathrm{pH}$ as follows.

$$
\begin{array}{ll}
\mathrm{Ce}^{3+}+2 \mathrm{H}_{2} \mathrm{O}=\mathrm{CeO}_{2}+4 \mathrm{H}^{+}+\mathrm{e}^{-} & K=10^{-21.32} \\
\mathrm{cCe}^{3+}=10^{\left(-4 \mathrm{pH}-\frac{F\left(\text { Eh }-E^{\circ}\right)}{2.3 R T}\right)} & E^{\circ}=1.258 \mathrm{~V}
\end{array}
$$

where the prefix "c" means that the calculated value of $\mathrm{Ce}^{3+}$ from $\mathrm{Eh}$ and $\mathrm{pH}$. The equilibrium constant $K$ is from Schumm et al. (1973) (Table 2) and then $E^{\circ}$ is calculated. We can understand whether chemical thermodynamics determined the behavior of Ce by comparing the concentrations of $\mathrm{Ce}(\mathrm{III})$ and $\mathrm{cCe}^{3+}$. All the data sets we examined had $\mathrm{pH}$ data, but only two publications (Dia et al., 


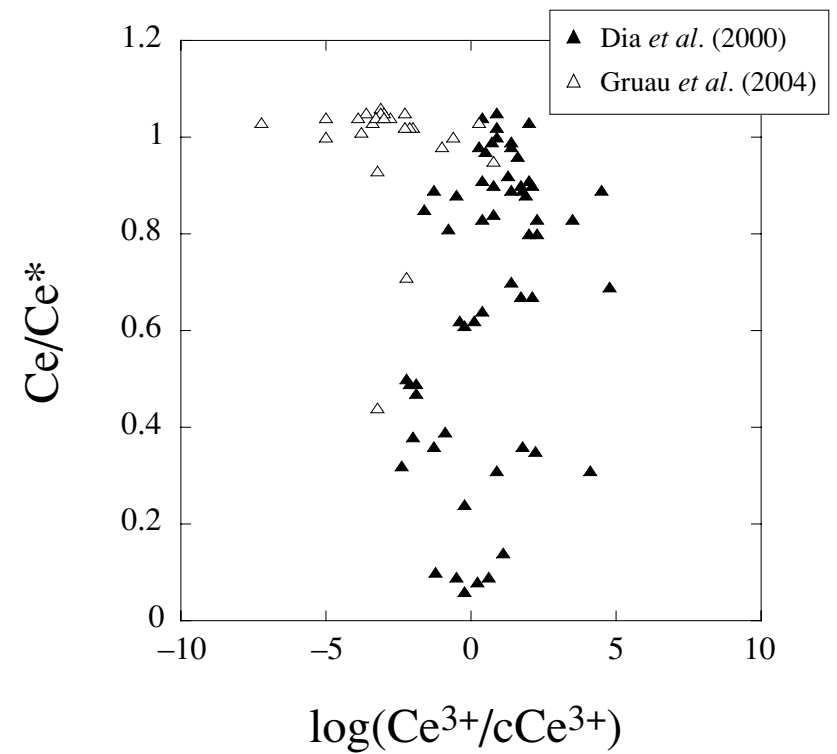

Fig. 6. Ce anomaly vs. $\mathrm{Ce}^{3+} / \mathrm{c} C$ e plot using the data reported by Dia et al. (2000) and Gruau et al. (2004) illustrating better consistency of actual and calculated Ce concentrations as Ce anomaly becomes deeper.

2000; Gruau et al., 2004) showed Eh data. The Eh values reported by Dia et al. (2000) ranged $250 \mathrm{mV}$ to $550 \mathrm{mV}$, while by Gruau et al. (2004) ranged $150 \mathrm{mV}$ to $400 \mathrm{mV}$. Figure 6 shows $\mathrm{Ce}$ anomalies plotted against $\mathrm{Ce}^{3+} / \mathrm{cCe}$, which is an indicator whether $\mathrm{Ce}^{3+}$ is saturated or not when all the assumptions introduced are appropriate, with the calculated data from two publications (Dia et al., 2000; Gruau et al., 2004). The ratio is an indicator of the discrepancy from the equilibrium of the reaction expressed in Eq. (2) and, when it is unity, the system may be at equilibrium. The value of $\mathrm{Ce}^{3+} / \mathrm{cCe}$ tends to become 1 as $\mathrm{Ce}$ anomaly becomes more negative, while the value widely scatters as negative Ce anomaly disappears. The accurate measurement of Eh in natural water is normally difficult (Bartlett, 1999). When the inaccuracy of Eh values is discounted, these results may imply the following. The concentration of $\mathrm{Ce}^{3+}$ may be determined more strictly by the $\mathrm{Ce}^{3+} / \mathrm{CeO}_{2}$ equilibrium when the deeper negative $\mathrm{Ce}$ anomaly appears; organic matter, however, might govern the $\mathrm{Ce}^{3+}$ concentration when there is no $\mathrm{Ce}$ anomaly.

To debate the relationship between negative $\mathrm{Ce}$ anomaly and redox condition for all data sets, we indirectly calculated Eh using Eq. (6), which is derived from Eq. (5), assuming the $\mathrm{Ce}^{3+} / \mathrm{CeO}_{2}$ equilibrium.

$$
\begin{array}{r}
c E h\left(\mathrm{pH}, \mathrm{Ce}^{3+}\right)=E^{\circ}-\frac{2.3 R T}{F}\left(4 \mathrm{pH}-\log \left[\mathrm{Ce}^{3+}\right]\right) \\
E^{\circ}=1.258 \mathrm{~V} .
\end{array}
$$

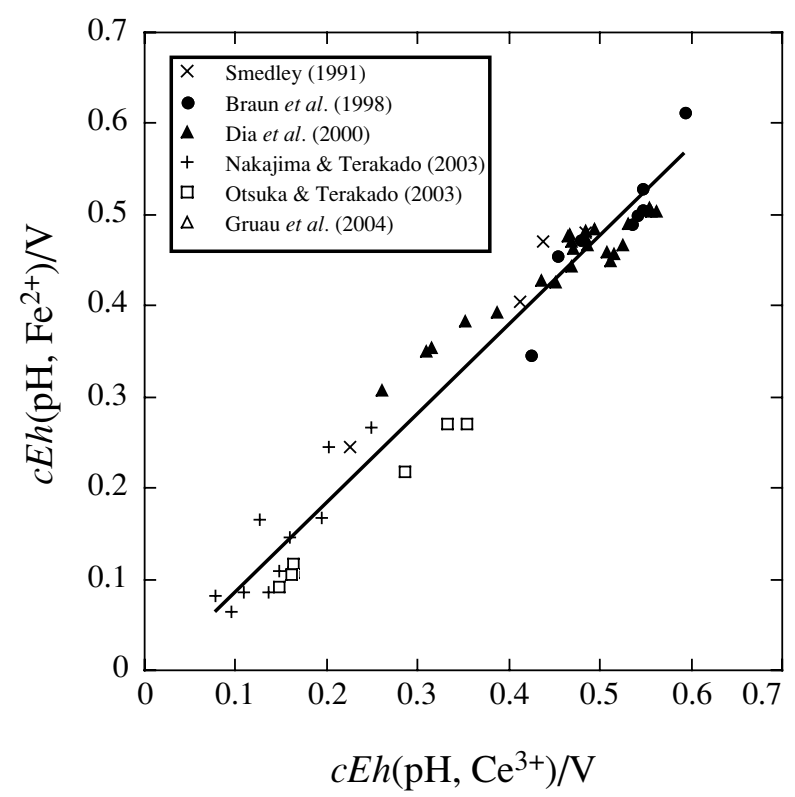

Fig. 7. Relationship between $c E h\left(p H, C e^{3+}\right)$ and $c E h\left(p H, F e^{2+}\right)$ for data set showing sharpe negative Ce anomaly $\left(\mathrm{Ce} / \mathrm{C} e^{*}<\right.$ 0.6). The lower cEh corresponds to the higher concentration of $\mathrm{Ce}$ or $\mathrm{Fe}$, whereas the higher cEh corresponds to the lower concentration of $\mathrm{Ce}$ or $\mathrm{Fe}$. The solid line shows a regression line for all data: $c E h\left(\mathrm{pH}, \mathrm{Ce}^{3+}\right)=0.976 \mathrm{cEh}\left(\mathrm{pH}, \mathrm{Fe}^{2+}\right)-0.012$, $r^{2}=0.95$.

Furthermore, assuming at a low $\mathrm{Fe}$ concentration that $\mathrm{Fe}$ is in equilibrium following $\mathrm{Fe}^{2+} / \mathrm{Fe}(\mathrm{OH})_{3}(\mathrm{am})$ reaction (Eq. (7)), Eh can also be calculated in a similar manner to $c E h\left(\mathrm{pH}, \mathrm{Ce}^{3+}\right)$ using Eq. (8).

$$
\begin{array}{r}
\mathrm{Fe}^{2+}+3 \mathrm{H}_{2} \mathrm{O}=\mathrm{Fe}(\mathrm{OH})_{3}(\mathrm{am})+3 \mathrm{H}^{+}+\mathrm{e}^{-} \\
K=10^{-25.59} \\
c E h\left(\mathrm{pH}, \mathrm{Fe}^{2+}\right)=E^{\circ}-\frac{2.3 R T}{F}\left(3 \mathrm{pH}-\log \left[\mathrm{Fe}^{2+}\right]\right) \\
E^{\circ}=1.065 \mathrm{~V} .
\end{array}
$$

The equilibrium constant $K$ and the standard redox potential $E^{\circ}$ are from Langmuir (1997) (Table 2). If the slope $\left(c E h\left(\mathrm{pH}, \mathrm{Fe}^{2+}\right) / c E h\left(\mathrm{pH}, \mathrm{Ce}^{3+}\right)\right)=1$, the concentrations of $\mathrm{Fe}^{2+}$ and $\mathrm{Ce}^{3+}$ are determined by in situ $\mathrm{pH}$ and Eh with the assumed equilibrium $\mathrm{Fe}^{2+} / \mathrm{Fe}(\mathrm{OH})_{3}(\mathrm{am})$ and $\mathrm{Ce}^{3+} / \mathrm{CeO}_{2}$, respectively. Whereas, if $c E h$ s depend more on $\mathrm{pH}$ (one of the explanatory variables), in other words, the concentrations of $\mathrm{Ce}$ and $\mathrm{Fe}$ are independent of $\mathrm{Eh}$, the slope would be close to 1.33 . Ce oxidation or scavenging of $\mathrm{Ce}$ is considered to take place during the initial precipitation of iron, where amorphous $\mathrm{Fe}(\mathrm{OH})_{3}$ is a major phase. $\mathrm{FeOOH}$ is a stable solid phase, which must be considered in the case of the dissolution process of iron. 
Here, the $\mathrm{FeOOH}$ phase has not been considered, as we are not looking at the reaction associated with the dissolution of iron ions. Iron carbonate species have also not been considered. The stability constant of $\mathrm{FeCO}_{3}$ reported by Langmuir (1997) indicates the carbonate phase can be important only when $\mathrm{pH}$ is greater than 7.5. Such high pHs are not seen in the data we cited except for one ground water sampled in Japan (Nakajima and Terakado, 2003; Otsuka and Terakado, 2003).

Figure 7 shows the relationship between $c E h\left(\mathrm{pH}, \mathrm{Ce}^{3+}\right)$ and $c E h\left(\mathrm{pH}, \mathrm{Fe}^{2+}\right)$ when only data displaying deep negative $\mathrm{Ce}$ anomalies $\left(\mathrm{Ce} / \mathrm{Ce}^{*}<0.6\right)$ are considered. The slope of the regression line is almost $1\left(c E h\left(\mathrm{pH}, \mathrm{Ce}^{3+}\right)=\right.$ $\left.0.976 c E h\left(\mathrm{pH}, \mathrm{Fe}^{2+}\right)-0.01, r^{2}=0.95\right)$, implying that solubilities of both $\mathrm{Ce}$ and $\mathrm{Fe}$ in waters similarly reflected $\mathrm{pH}$ and $\mathrm{Eh}$ of the waters. It should be noted that the intercept of the regression line is zero considering the range of uncertainty. This suggests that the concentration of $\mathrm{Ce}$ may be determined by the simple $\mathrm{Ce}^{3+} / \mathrm{CeO}_{2}$ reaction in water with a $\mathrm{Ce}$ anomaly. The good agreement of $c E h(\mathrm{pH}$, $\left.\mathrm{Fe}^{2+}\right)$ and $c E h\left(\mathrm{pH}, \mathrm{Ce}^{3+}\right)$ may be an indication that the solid phases are much simpler than we have considered when Ce anomaly is seen with void of complicated DOC in systems.

\section{CONCLUSIONS}

As far as the nine publications are considered, conditions where terrestrial water develops a negative $\mathrm{Ce}$ anomaly must satisfy all the following conditions: (i) $\mathrm{Fe}$ and $\mathrm{Mn}<10^{-5} \mathrm{~mol} / \mathrm{L}$ and (ii) $\mathrm{DOC}<10 \mathrm{mg} / \mathrm{L}$. Although more detailed investigations are necessary to obtain a more general conclusion, we consider that the negative Ce anomaly may reflect water chemistry only at organicpoor conditions.

The agreement between $c E h\left(\mathrm{pH}, \mathrm{Ce}^{3+}\right)$ and $c E h(\mathrm{pH}$, $\left.\mathrm{Fe}^{2+}\right)$ in terrestrial water may imply the following: when $\mathrm{Ce}$ anomaly appears, the solubility of $\mathrm{Ce}$ can be determined by $\mathrm{Ce}^{3+} / \mathrm{CeO}_{2}$ equilibrium. It implies that the absolute concentration of $\mathrm{Ce}$ might possess meaningful in situ redox information. Therefore, most discussions based on Ce anomaly, a concentration relative to those of neighboring elements, would lead us to irrelevant discussion. Although it should be noticed that $\mathrm{Ce}$ is not an accurate indicator of in situ $\mathrm{pH}$ and Eh condition with quite a wide range of uncertainty involved, as shown in Fig. 3, the agreement of $c E h\left(\mathrm{pH}, \mathrm{Ce}^{3+}\right)$ and $c E h\left(\mathrm{pH}, \mathrm{Fe}^{2+}\right)$ is worth discussing. Bartlett (1999) pointed out that a Pt electrode may not reflect changes in some species involved in redox reactions and that neither $\mathrm{Mn}$ or $\mathrm{Fe}$ oxides nor nitrate had the expected quantitative effect on the Pt electrode measurement. It implies that the redox condition of natural water could be better understood by $\mathrm{Ce}$ and $\mathrm{Fe}$ data than in situ Eh measurement.
Acknowledgments - This study was supported partly by a scholarship of the Japan Society for the Promotion of Science (JSPS) (No. 181285). Dr. O. Pourret is acknowledged for useful comments and Dr. Y. Takahashi is acknowledged for editorial handling.

\section{REFERENCES}

Akagi, T. and Masuda, A. (1998) A simple thermodynamic interpretation of Ce anomaly. Geochem. J. 32, 301-314.

Bartlett, R. J. (1999) Characterizing soil redox behavior. Soil Physical Chemistry (Sparks, D. L., ed.), 2nd ed., 371-397, CRC Press, Boca Raton, FL.

Bau, M. (1999) Scavenging of dissolved yttrium and rare earths by precipitating iron oxyhydroxide: Experimental evidence for Ce oxidation, Y-Ho fractionation, and lanthanide tetrad effect. Geochim. Cosmochim. Acta 63(1), 67-77.

Bessoles, B. and Lasserre, M. (1977) Le complexe de base du Cameroun. Bull. Soc. Géol. Fr. 19, 1085-1092.

Braun, J. J., Pagel, M., Muller, J. P., Bilong, P., Michard, A. and Guillet, B. (1990) Cerium anomalies in lateritic profiles. Geochim. Cosmochim. Acta 51, 597-605.

Braun, J. J., Viers, J., Dupré, B., Polve, M., Ndam, J. and Muller, J. (1998) Solid/liquid REE fractionation in the lateritic system of Goyoum, East Cameroon: The implication for the present dynamics of the soil covers of the humid tropical regions. Geochim. Cosmochim. Acta 62(2), 273-299.

Brookins, D. G. (1983) Eh-pH diagrams for the rare earth elements at $25^{\circ} \mathrm{C}$ and one bar pressure. Geochem. J. 17, 223229.

Byrne, R. H. and Sholkovitz, E. R. (1996) Marine chemistry and geochemistry of the lanthanids. Handbook on the Physics and Chemistry of Rare Earth, Vol. 23 (Gschneidner, K. A., Jr. and Eyring, L. R., eds.), 497-593, Elsevier Sciences B.V.

Davranche, M., Pourret, O., Gruau, G. and Dia, A. (2004) Impact of humate complexation on the adsorption of REE onto Fe oxyhydroxide. J. Colloid Interface Sci. 277, 271-279.

Davranche, M., Pourret, O., Gruau, G., Dia, A. and Le CozBouhnik, M. (2005) Adsorption of REE(III)-humate complexes onto $\mathrm{MnO}_{2}$ : Experimental evidence for cerium anomaly and lanthanide tetrad effect suppression. Geochim. Cosmochim. Acta 69(20), 4825-4835.

De Baar, H. J. W., German, C. R., Elderfield, H. and van Gaans, P. (1988) Rare earth element distributions in anoxic waters of the Cariaco Trench. Geochim. Cosmochim. Acta 52, 1203-1219.

De Carlo, E. H., Wen, X.-I. and Irving, M. (1998) The influence of redox reactions on the uptake of dissolved Ce by suspended Fe and Mn oxide particles. Aquat. Geochem. 3, 357-389.

Dia, A., Gruau, G., Olivié-Lauquet, G., Riou, C., Molenat, J. and Curmi, P. (2000) The distribution of rare earth elements in groundwaters: Assessing the role of source-rock composition, redox changes and colloidal particles. Geochim. Cosmochim. Acta 64(24), 4131-4151.

Dupré, B., Gaillardet, J., Rousseau, D. and Allègre, C. J. (1996) Major and trace elements of river-borne material: The Congo Basin. Geochim. Cosmochim. Acta 60, 1301-1321. 
Elderfield, H., Upstill-Goddard, R. and Sholkovitz, E. R. (1990) The rare earth elements in rivers, estuaries, and coastal seas and their significance to the composition of ocean waters. Geochim. Cosmochim. Acta 54, 971-991.

Gaillardet, J., Dupré, B., Allègre, C. J. and Négrel, P. (1997) Chemical and physical denudation in the Amazon River Basin. Chem. Geol. 142, 141-173.

Goldstein, S. J. and Jacobsen, S. B. (1988) Rare earth elements in river waters. Earth Planet. Sci. Lett. 89, 35-47.

Gruau, G., Dia, A., Olivié-Lauquet, G., Davranche, M. and Pinay, G. (2004) Controls on the distribution of rare earth elements in shallow groundwaters. Water Res. 38, 35763586.

Hall, G. E. M., Vaive, J. E. and McConnell, J. W. (1995) Development and application of a sensitive and rapid analytical method to determine the rare-earth elements in surface waters. Chem. Geol. 120, 91-109.

Hellman, P. L. and Henderson, P. (1977) Are rare earth elements mobile during spilitisation? Nature 267, 38-40.

Johannesson, K. H. and Burdige, D. J. (2007) Balancing the global oceanic neodymium budget: Evaluating the role of groundwater. Earth Planet. Sci. Lett. 253, 129-142.

Johannesson, K. H., Tang, J., Daniels, J. M., Bounds, W. J. and Burdige, D. J. (2004) Rare earth element concentrations and speciation in organic-rich blackwaters of the Great Dismal Swamp, Virginia, USA. Chem. Geol. 209, 271-294.

Klungness, G. D. and Byrne, R. H. (2000) Comparative hydrolysis behavior of the rare earths and yttrium: the influence of temperature and ionic strength. Polyhedron 19, 99107.

Koeppenkastrop, D. and De Carlo, E. H. (1992) Sorption of rare-earth elements from seawater onto synthetic mineral particles: An experimental approach. Chem. Geol.95, 251263.

Koppi, A. J., Edis, R., Field, D. J., Geering, H. R., Klessa, D. A. and Cockayne, D. J. H. (1996) Rare earth trends and cerium-uranium-manganese associations in weathered rock from Koongarra, Northern Territory, Australia. Geochim. Cosmochim. Acta 60, 1695-1707.

Langmuir, D. (1997) Aqueous Environmental Geochemistry. 90-93, Prentice-Hall, Inc., New Jersey, 600 pp.

Lawrence, M. G. and Kamber, B. S. (2006) The behaviour of rare earth elements during estuarine mixing-revisited. Mar. Chem. 100, 147-161.

Lawrence, M. G., Greig, A., Collerson, K. D. and Kamber, B. S. (2006) Rare Earth Element and Yttrium Variability in South East Queensland Waterways. Aquat. Geochem. 12, 39-72.

Matsunaga, T., Karametaxas, G., Von Gunten, H. R. and Lichtner, P. C. (1993) Redox chemistry of iron and manganese minerals in river-recharged aquifers: A model interpretation of a column experiment. Geochim. Cosmochim. Acta 57, 1691-1704.

Millero, F. J. (1992) Stability constants for the formation of rare earth inorganic complexes as a function of ionic strength. Geochim. Cosmochim. Acta 56, 3123-3132.

Moffett, J. W. (1990) Microbially mediated cerium oxidation in sea water. Nature 345, 421-423.

Nakajima, T. and Terakado, Y. (2003) Rare earth elements in stream waters from the Rokko granite area, Japan: Effect of weathering degree of watershed rocks. Geochem. J. 37, 181-198.

Nesbitt, H. W. (1979) Mobility and fractionation of rare earth elements during weathering of a granodiorite. Nature $\mathbf{2 7 9}$, 206-210.

Nordstom, D. K., Plummer, L. K., Langmuir, D., Busenberg, E., May, H. M., Jones, B. F. and Parkhurst, D. L. (1990) Revised chemical equilibrium data for major water-mineral reactions and their limitations. Chemical Modeling of Aqueous Systems II: ACS Symposium Series 416, 398-413, American Chemical Society.

Ohta, A. and Kawabe, I. (2001) REE(III) adsorption onto Mn dioxide $\left(\delta-\mathrm{MnO}_{2}\right)$ and $\mathrm{Fe}$ oxyhydroxide: $\mathrm{Ce}(\mathrm{III})$ oxidation by $\delta-\mathrm{MnO}_{2}$. Geochim. Cosmochim. Acta 65(5), 695-703.

Otsuka, M. and Terakado, Y. (2003) Rare Earth element abundance in high phosphorus and low iron groundwaters from the Nishinomiya district, Japan: Variation in Ce anomaly, redox state and heavy rare earth enrichment. Geochem. J. 37, 1-19.

Patino, L. C., Velbel, M. A., Price, J. R. and Wade, J. A. (2003) Trace element mobility during spheroidal weathering of basalts and andesites in Hawaii and Guatemala. Chem. Geol. 202, 343-364.

Pourret, O., Davranche, M., Gruau, G. and Dia, A. (2007a) Organic complexation of rare earth elements in natural waters: Evaluating model calculations from ultrafiltration data. Geochim. Cosmochim. Acta 71, 2718-2735.

Pourret, O., Dia, A., Davranche, M., Gruau, G., Hénin, O. and Angée, M. (2007b) Organo-colloidal control on major- and trace-element partitioning in shallow ground waters: Confronting ultrafiltration and modeling. Appl. Geochem. 22, 1568-1582.

Pourret, O., Davranche, M., Gruau, G. and Dia, A. (2007c) Rare Earth Elements complexation with humic acid. Chem. Geol. 243, 128-141.

Schijf, J. and Byrne, R. H. (2004) Determination of $\mathrm{SO}_{4} \mathrm{~B}_{1}$ for yttrium and the rare earth elements at $I=0.66 \mathrm{~m}$ and $t=$ $25^{\circ} \mathrm{C}$-Implications for YREE solution speciation in sulfaterich waters. Geochim. Cosmochim. Acta 68, 2825-2837.

Schumm, R. M., Wagman, D. D., Bailey, S. M., Evans, W. H. and Parker, V. B. (1973) Selected values of chemical thermodynamic properties. Table for the lanthanide elements (elements 62 through 76 in the standard order arrangement). National Bureau of Standards Technical Note 270, 7.

Sholkovitz, E. R. (1993) The geochemistry of rare earth elements in the Amazon River estuary. Geochim. Cosmochim. Acta 57, 2181-2190.

Sholkovitz, E. R. (1995) The aquatic chemistry of rare earth elements in rivers and estuaries. Aquat. Geochem. 1, 1-34.

Smedley, P. (1991) The geochemistry of rare earth elements in groundwater from the Carnmenelis area, southwest England. Geochim. Cosmochim. Acta 55, 2767-2779.

Sonke, J. E. and Salters, V. J. M. (2006) Lanthanide-humic substances complexation. I. Experimental evidence for a lanthanide contraction effect. Geochim. Cosmochim. Acta 70, 1495-1506.

Stern, J. C., Sonke, J. E. and Salters, V. J. M. (2007) A capillary electrophoresis-ICP-MS study of Rare Earth Element 
complexation by humic acids. Chem. Geol. 246, 170-180. Tang, J. and Johannesson, K. H. (2003) Speciation of rare earth elements in natural terrestrial waters: assessing the role of dissolved organic matter from the modeling approach. Geochim. Cosmochim. Acta 67(13), 2301-2513.

Ward, C. D. (1986) Rare earth element mobility and fractionation during weathering of the Dartmoor granite, southwestern England. Fifth International Symposium on Water-Rock Interaction, 612-616.

Wood, S. A. (1990) The aqueous geochemistry of the Rare-Earth Elements and yttrium. 1. Review of available low-temperature data for inorganic complexes and the inorganic REE speciation of natural waters. Chem. Geol. 82, 159-186.

\section{APPENDIX}

The observed values of $\mathrm{Ce}$ concentrations in the reports represent not the free $\mathrm{Ce}^{3+}$ concentrations, but the total trivalent and tetravalent cerium concentrations, $\Sigma \mathrm{Ce}$ of the water studied. We assumed that dissolved Ce fraction could be approximated by $\Sigma \mathrm{Ce}$ in a organic-poor condition and the free $\mathrm{Ce}^{3+}$ concentrations were approximated from complexation mass-balance and equilibria equations (Langmuir, 1997):

$$
\begin{aligned}
& {\left[\mathrm{Ce}^{3+}\right]} \\
& =\sum \mathrm{Ce} /\left\{1+10^{3.59}\left[\mathrm{SO}_{4}^{2-}\right]+10^{2.31}\left[\mathrm{HCO}_{3}^{-}\right]+10^{7.06}\left[\mathrm{CO}_{3}^{2-}\right]\right. \\
& \left.+10^{11.76}\left[\mathrm{CO}_{3}^{2-}\right]^{2}+10^{-8.34}\left[10^{-\mathrm{pH}}\right]+10^{-15.0}\left[10^{-\mathrm{pH}}\right]^{2}\right\} .
\end{aligned}
$$

The thermodynamic constants used in this study are listed in Table 2. Although the stability constants are a function of ionic strength and temperature (e.g., Millero, 1992), we thoroughly used stability constants at $25^{\circ} \mathrm{C}$ and zero ionic strength as we only referred the data for fresh water sites, which ionic strengths are low (majority of the samples had $I<0.01)$. The possible species $\mathrm{CeSO}_{4}{ }^{+}$, $\mathrm{CeHCO}_{3}{ }^{2+}, \mathrm{CeCO}_{3}{ }^{+}, \mathrm{CeOH}_{2}{ }^{+}$and $\mathrm{Ce}(\mathrm{OH})^{2+}$ were considered. The fraction of free $\mathrm{Ce}^{3+}$ calculated from Eq. (A1) for the waters we have used ranged from 0.1 to $80 \%$ of $\sum \mathrm{Ce}$, whereas that of free $\mathrm{Fe}^{2+}$ (calculated using (A2)) was always greater than $60 \%$. The error in Eh resulting from the error in the estimation of free $\mathrm{Ce}^{3+}$ is considered to be insignificant considering the range of uncertainty in discussion, since an error by one order of magnitude in the free $\mathrm{Ce}^{3+}$ fraction corresponds to only 0.026 $\mathrm{V}$ error in $c E h\left(\mathrm{pH}, \mathrm{Ce}^{3+}\right)$. Some samples void of $\mathrm{SO}_{4}{ }^{2-}$ data were excluded in the discussions, as $\mathrm{SO}_{4}{ }^{2-}$ complex may become quite significant in certain environments (Schijf and Byrne, 2004). If the data sets did not include carbonate ion, the concentration of $\mathrm{HCO}_{3}{ }^{-}$and $\mathrm{CO}_{3}{ }^{2-}$ were estimated from $\mathrm{pH}$ assuming the equilibrium with 300 $\mathrm{ppmVCO}_{2}$ air at each site. The complexation with dissolved organic matter (DOM) was not considered due to the ambiguous information of DOM and the complication involved in the reaction between Ce and DOM, although REEs can be strongly complexed by organic matter due to their high stability constants with some specific compounds (Ohta and Kawabe, 2001; Tang and Johannesson, 2003). We also considered that the Ce complex with DOC is negligible when DOC $<10 \mathrm{mg} / \mathrm{L}$.

The observed values of $\mathrm{Fe}$ concentrations in the reports represent not the free $\mathrm{Fe}^{2+}$ concentrations but the $\sum F e$ that includes dissolved, colloidal and small particulate. Free $\mathrm{Fe}^{2+}$ was obtained in a similar manner to that for free $\mathrm{Ce}^{3+}$ introducing similar assumptions 